\title{
5 \\ Election observation missions to the 2006 Fiji election
}

\section{Graham Hassall and Jeannette Bolenga ${ }^{1}$}

Never believe what you read in the papers and particularly from observers who are paid a lot of money for a tropical holiday (Internet chatter)

The general feeling of unease in Fijian society in the lead-up to the 2006 general election made the presence of election observers of more than academic interest. In his statement of 1 March 2006, announcing that the election would be held over the period 6-13 May, Prime Minister Qarase extended invitations to seven potential observer groups. A media release from the Ministry of Information, Communications and Media Relations stated:

The Prime Minister... announced that on behalf of Government, he would be extending invitations to the Commonwealth, the United Nations, the European Union, the Pacific Islands Forum, and, bilaterally, to Australia and NZ, to send Observers to monitor the Elections in Fiji. The PM will also write to the Vice Chancellor of the USP [the University of the South Pacific] to invite its School of Governance to monitor the Elections in close liaison and co-ordination with the Office of the Supervisor of Elections. Mr Qarase explained that Government was doing this because it has full confidence in the Electoral Commission and the Office of the Supervisor of Elections in independently conducting the General Elections in a free, open, fair and impartial manner, and with full transparency. ${ }^{2}$

The invited organizations undertook observer missions of differing scale and emphasis, although each in its own way in accord with the Electoral Act 1998 and a set of 'Guidelines for International Electoral Observers' supplied by the Fiji Elections Office. From the government's point of view, the presence of observers no doubt added to the transparency of the democratic exercise it 
was about to undertake. The invitation was both a sign to the international community that the government was confident of the ability of the Elections Office to implement the election, and an acknowledgement that some of Fiji's multilateral and bilateral partners had concerns about the election on the basis of Fiji's turbulent recent past (not to mention that Australia, New Zealand and the European Community had each donated substantial sums to help cover the costs of the exercise).

Others apart from the government called for observer presence at the 2006 election. For example, in September 2005, while the Commonwealth Parliamentary Association was meeting in Fiji, opposition leader Mahendra Chaudhry asked the Commonwealth Secretary General to send a monitoring group, citing election abuses of 2001 as a reason. ${ }^{3}$

\section{Earlier Fiji elections}

International observer groups had attended Fiji's general election in August 2001 following a request from the Fiji government to the United Nations (UN) - in response to which a UN Electoral Observer Mission was approved by resolution of the Fifty-fifth General Assembly '... as part of the effort to promote and consolidate new or restored democracies'. Japan announced grant assistance of US\$370,000 and ten support staff. At least 55 international observers were accredited for the 2001 poll -40 represented the United Nations, 12 represented the Commonwealth Secretariat, and three represented the European Union (EU). ${ }^{5}$ The UN report found the elections to be credible while expressing concern about technical problems '... including serious issues related to the electoral rolls'; about the 'unnecessarily complex' preferential voting system; and about the requirement of section 99 of the constitution for a multiparty cabinet to be established. ${ }^{6}$

\section{The origin and purpose of observer missions}

The practice of election observation has evolved rapidly in recent years, with standards emerging for long-, medium- and short-term observations. Among the lead agencies that have established guidelines are IFES $^{7}$ in North America, International IDEA ${ }^{8}$ in Europe, and the UN Elections Office. In October 2005, 21 lead agencies gathered in New York to endorse the 'Declaration of Principles for International Election Observation'. 
Within the Asia Pacific region, the practice of observation emerged in such divergent circumstances as the post-Marcos years in the Philippines and the relatively more staid political environments of Australia and New Zealand. The Australian Electoral Commission regularly invites electoral experts and practitioners to participate in observation of Australian general elections. The PIANZEA (Pacific Islands, Australia and New Zealand Electoral Administrators) network, which links the electoral commissions of Australia, New Zealand and the Pacific Islands, has also coordinated a number of election observation missions in the region.

The inclusion of a non-government international observer group, based in the Governance Program at USP, reflected the government's awareness of that program's interest in the development of electoral practices in Pacific Island countries. The USP had formally applied for status on 15 February, and this was granted by Supervisor of Elections Semesa Karavaki on 10 March, pursuant to the announcement made nine days earlier by the Prime Minister. In granting observer status the Supervisor commented:

I am pleased to provide Observer accreditation to you and your team from the Electoral Studies Unit at the Pacific Institute of Advanced Studies in Development and Governance, USP ...I fully support your Goal and Objectives. Independent observers have a vital role to play in any election and as outlined in Objective 7 of your Terms of Reference I am looking forward to your Report and any recommendations you may have which might improve the relevant Legislation and the procedures we use in the Elections Office. ${ }^{9}$

By the time of polling, 6-13 May, several additional observer groups had been given accreditation, and yet others came to Fiji to observe in an unofficial capacity. The PIANZEA network gathered a team of eight observers, from four regional countries - although there was no formal reporting process or coordination. Officials from the Papua New Guinea Electoral Commission came to learn any lessons in advance of their general election, scheduled for 2007. Transparency International sponsored a delegate from its Vanuatu branch. Due to the short time frame, the United Nations was unable to organize a mission.

In broad terms, each observer mission was interested in whether or not the elections were conducted in a 'free and fair' manner. No doubt the EU, following through with its interest in Fiji since 2000, had one eye on post- 
conflict restoration of democracy and the rule of law, and the other on ACP relations $s^{10}$ and the future of the sugar industry. The Commonwealth, which has been monitoring the restoration of the rule of law in Fiji over a period of time, fielded a six-member team led by Keith Knight and including one Pacific Islander (Paul Bengo, Registrar of Political Parties in Papua New Guinea) and five additional experienced election-watchers. ${ }^{11}$

The 39-member EU observer mission was the best funded (with approximately FJ\$2.4 million), most organized, and most visible (not least due to its accommodation at the Holiday Inn of its international observers and support staff). An advance team visited Fiji in March to gauge the viability of mounting an observation exercise and to determine its scope. Having decided to proceed, twelve 'long-term' observers arrived in Fiji on 10 April, and were despatched in pairs to six regions around the country. A further twelve shortterm observers arrived prior to polling; they were also dispersed across the islands after an intensive period of induction and orientation. Nine members of the group were EU staff resident in Fiji. Additional staff were sourced locally to monitor media and provide logistical support. Local academics and specialists were engaged to provide background briefings at a pre-poll retreat. Chief observer Istvan Szent-Ivanyi, a Hungarian representative to the European Parliament, arrived on 3 May, shortly before polling commenced on the sixth. The mission announced that its report would be issued at the end of August.

The 23-person Pacific Islands Forum team was led by Forum SecretaryGeneral Greg Urwin. Rather than organizing an independent program, the New Zealand government contributed nine observers to the Forum team. Although the Australian Government did not send an observer group, five diplomats from the Australian High Commission in Suva were registered as 'independent observers'. Fiji resident and New Zealand citizen Father David Arms was the single independent observer not attached to a diplomatic mission or university team. The United States Embassy accredited 15 observers and the New Zealand High Commission, three.

The Governance Program at USP organized a 16-member observer team, comprising faculty members, students and administrative staff. ${ }^{12}$ Smaller teams of two or three persons had previously observed general elections in Cook Islands (2004), Vanuatu (2004), Solomon Islands (2006) and Samoa (2006), under 
a three-year EU-funded program, 'Transforming our Communities through Good Governance', run at PIAS-DG. ${ }^{13}$ The much larger exercise in Fiji was made possible by the fact that all participants were living in the country, as well as by a general expectation that the Electoral Studies project at PIAS-DG would take on this civic role, particularly as no domestic observation teams were permitted. A budget of approximately $\$ 20,000$ was established. Teams volunteered to observe in each of Fiji's four districts (although an effort to have an observer travel to Rotuma was thwarted - reportedly by excess rain on the island's airstrip).

\section{Observer accreditation, orientation and coordination}

The Supervisor of Elections commissioned a consultant to take responsibility for accreditation and coordination of observer missions. Only 'international' missions were allowed, and members of these missions were required to obtain formal accreditation. ${ }^{14}$ This required their agreement to comply with guidelines for observers provided by the Elections Office. ${ }^{15}$ No applications were denied by the Elections Office, and 121 observers were accredited.

Observation was defined to include observation and evaluation of the impartiality and functioning of the Office of the Supervisor of Elections and its team of electoral officials; the voter registration process and the establishment of the electoral roll; the voter education campaign; the election campaign; the voting process; the vote count; the determination of electoral results and their dissemination; and access to and use of the media. ${ }^{16}$

International observation was defined as commencing 'when International Electoral Observers have arrived in Fiji and have received their identity documents confirming their accreditation by the Office of the Supervisor of Elections' and ending 'with the departure of the Observer Group from Fiji'. ${ }^{17}$ No Fiji citizens could participate in international observer missions. ${ }^{18}$ Once accredited, observers had the right to obtain a visa, to move freely throughout the country, and to communicate freely with all parties involved in the elections in some way, including political parties, other social and political organizations, and officials involved in electoral processes. They were to communicate their findings to the Office of the Supervisor of Elections and seek his response before making these views public. ${ }^{19}$ 
In return for this access to all facets of the election process, international observers accepted a number of obligations: they agreed to respect the constitution and the laws of Fiji, to exercise their role with 'impartiality, independence and objectivity', and to wear their identity cards at all times. ${ }^{20}$ While they could not 'interfere in, or impede, the normal course of the electoral process' and were to '...refrain from issuing individual statements about the electoral process to the media', they had an obligation to '.. notify electoral officials of any action or conduct which they believe to be serious infringements of the electoral process ${ }^{21}$ Diplomats accredited in Fiji and who were 'designated as International Observers', were free to '... exercise their functions without prejudice to the provisions of the Vienna Convention on Diplomatic Relations'. ${ }^{22}$

Upon accreditation, observers were provided with copies of all relevant legal and constitutional provisions, and with the Elections Office's policy manuals. The Fiji government's Information, Technology and Computing Department provided IT support to the Elections Office website (http://www.elections.gov. fj), at which information on constituencies, candidates, parties and electoral provisions was regularly updated. Immediately prior to polling, the Elections Office provided a one-day induction for international observers and, during the polling and count periods, observers benefited from the Supervisor of Elections' daily press briefings.

Shortly before polling commenced, observer missions met with each other and with major players in the electoral process, partly to share thoughts on how each group felt the process was proceeding, but also in an effort to collaborate and avoid duplication in fieldwork. However, while these meetings brought familiarity with each group's composition and strategies, they did not result in significant cooperation in practical terms.

\section{Determining observer mission effectiveness}

Radio New Zealand International reported that more than 100 observers 'from the EU, the Commonwealth, the Pacific Forum and the USP' had assembled to monitor the elections. ${ }^{23}$ Given that one assessment put the cost of observer missions to the Fiji 2006 election at FJ \$4.7 million (and the cost of the election exercise as a whole at FJ $\$ 48$ million), ${ }^{24}$ questions concerning the value of 
observer missions are clearly worth asking. At the same time, one may ask whether or not international observers had any particular training or expertise that would allow them to make pronouncements as to whether the elections were 'free and fair'. A related question concerns whether or not electoral actors have taken any lessons whatsoever from previous observation reports.

\section{The impact of fieldwork}

Although observer missions were not to interfere or intervene in any way in electoral processes and were to remain as neutral as possible, there can be no doubt that the presence of so many observers had an impact on political actors, if not on the election outcome itself. The major parties expressed their support for the presence of observer teams, each pointing to issues that required careful watching. ${ }^{25}$ The National Federation Party, for instance, called on international election observers to 'observe the deliberate breaches of section 134 of the Electoral Act'; it was concerned about parties continuing to use the media to conduct campaigns, and at advertisements that included the Fiji Labour Party banner appearing in papers during election week. ${ }^{26}$ Some parties and NGOs shared their concerns about aspects of the campaign by faxing letters to observer missions. Experience in the field suggests that some polling officials were more welcoming of election observers at polling stations than they were of the media, even though the media carried identity cards that gave them equal status. Does this point to the need for more civics education for officials on the role of the media during elections?

\section{Observer missions and media}

The observer missions were interested in how various media outlets reported the election, and in freedom of speech in general. The EU mission, in particular, undertook extensive media content analysis. On 19 May the Fiji Daily Post printed a small item in which the EU mission described the newspaper's election coverage as having 'a general tendency to report in neutral tone' - with 34.7 per cent of coverage going to the Fiji Labour Party and 28.5 per cent to the Soqosoqo Duavata ni Lewenivanua. ${ }^{27}$

For its part, the media reported the activities of observers and were keen to solicit opinions on 'the topic of the day'. Because voting proceeded over ten 
days and because observers were required to withhold judgemental commentary until completion of their observation period (and to avoid statements made as individuals, as opposed to the joint statement issued by the group as a whole), the observer presence was reported widely, but without substantial commentary. This did not stop the media from associating 'neutral' observers with political issues of the period. Fiji Daily Post, for instance, addressed the military commander with such headlines as "PSSST! WATCH IT FRANK!", 28 and used editorial space to urge observer groups to take note of attitudes expressed by the military. ${ }^{29}$

\section{The impact of statements}

The official and informal statements of observer missions had unavoidable impacts on public opinion. Virtually all groups observed a common set of problems (errors and omissions on the roll; inadequate supply of ballot papers; last-minute changes to polling-booth locations, etc), but no group reported evidence of intentional manipulation of rolls, ballots, or counts. Whereas some defeated candidates and parties offered their alleged evidence of (or at least hinted at motivations behind) intentional foul-play, such claims failed to gain support in the public mind, or in the views of the observer teams. The results that were announced, no matter how polarized they appeared in terms of ethnically defined voting patterns, were consequently accepted by the voters in general. The presence of so many observers in the field, paying particular attention to the manner of the opening and closing of polling stations, the security of ballot boxes during transportation to the count centres, and the integrity of the counting process, made it difficult for claims of ballot fraud to be sustained. The presence of observers seemed to have a similar effect on claims that ballots printed in excess of officially required quantities were somehow moved from the government printer and used in one or other constituency. Observers had full access to the premises of the government printer at Vatuwaqa and their presence, together with that of numerous other agents, including police personnel, made the prospect of ballot-smuggling highly improbable.

It is not clear which observer missions first directed their findings to the Supervisor of Elections, as required by Article 7 of the International Code. The Head of the EU's Electoral Observation Mission, Istvan Szent-Ivanyi, 
tabled a report on the election in the European Parliament's 'Committee on Development' on 30 May, ${ }^{30}$ well ahead of the Mission's return visit to Fiji to make its final report at the end of August.

The Commonwealth mission's 'Statement on Voting' of 14 May suggested that while there were some shortcomings, the process was 'reasonably well managed'. The full statement, together with a picture of the team, appeared on page five of the Fiji Daily Post. ${ }^{31}$ The Commonwealth mission's 'Statement on the Counting and on the Electoral Process as a Whole' of 19 May called the election 'credible' and, while expressing concern about shortfalls in electoral administration (notably problems with voter registration and with late distribution of ballot papers), focused on the 'challenge of representation based on ethnicity. ${ }^{32}$ On 20 May the head of the Commonwealth mission, Mr K.D. Knight, publicly requested the commander of the Republic of Fiji Military Forces to accept the results and to refrain from interfering in politics - mentioning at the same time his preference that the electoral system move away from its ethnic basis.

On 2 June, the final report of the Commonwealth mission was submitted to the Commonwealth Secretary-General, who forwarded it the following week to the Prime Minister of Fiji, the chairman of the Electoral Commission, the Supervisor of Elections, the leaders of the main political parties and Commonwealth governments. It was released to the media on 12 June 2006.

At the outset of its mission the Forum Secretariat team announced it would issue a statement to the Elections Office, to the government, and then to forum member countries. ${ }^{33}$ It declared the results 'free and fair' on 15 May. ${ }^{34}$

The USP team issued a statement on 15 May that was reproduced in the Fiji Daily Post on 16 May. ${ }^{35}$ Although small deviations from proper procedures were observed, the group commended the untiring efforts of election officials and the police who worked alongside them, especially given the short time frame between the date the elections were called, 1 March, and the date polling began, 6 May.

The EU mission issued a preliminary statement on 18 May that appeared in the press the following day. ${ }^{36} \mathrm{In}$ it, the EU commented on electoral administration, voter registration, electoral campaigns, media coverage, complaints and appeals, participation of women, postal voting, voting and 
counting. Amongst other things, the report noted that the Elections Office had received a total of 65 written complaints, but noted that the procedure for the hearing of these complaints was not clear, and the results of the hearings were not to be made public.

The broad outlines of each observer mission report contained similar themes and concerns: inadequacies in registration, ballot printing and distribution, and identification of polling stations; the high number of invalid votes; and the handling of postal and overseas votes.

After the election observation exercise, questions will continue to be asked about its utility and effectiveness. Did the presence of such a large collection of international observers influence the behaviour of any of the most significant actors? Did the army become more restrained after an informal information session between the commander of the armed forces and EU representative Szent-Ivanyi? Did losing candidates and parties limit their post-ballot protests on account of the 'second opinion' that observers were able to offer the public? Did individual scrutineers, returning officers and polling agencies alter their activities by reason of the fact that an observer might suddenly appear at the door? Answering such questions is not at all easy, but the reporting of some 100 observers, who had nothing invested in the outcome of the poll apart from concern for the condition of democracy in Fiji and for the integrity of the country's system of government, appears to have given the public a sense of ease about the outcome that made it possible to move to the next difficult item - formation of government.

\section{Notes}

1 The authors acknowledge the research support of Mosmi Bhim and Amrita Nand, and additional information from Mark Borg and Gyan Deo.

2 Ministry of Information, Communications and Media Relations. 'Prime Minister announces 2006 general election dates'. Media release, 1 March 2006.

3 'Fiji opposition to lobby for election monitors'. PACNEWS, 5 September 2005.

4 United Nations. Secretary General. 2001. Support by the United Nations system of the efforts of Governments to promote and consolidate new or restored democracies. United Nations Electoral Observer Mission for the general elections in Fiji in August 2001, General Assembly. 56th Session. Agenda item 35. UNGA document A/55/L.90.

5 UNDP project. Fiji Elections 2001. <http://www.undp.org.fj/elections/Media/index.htm> (accessed 15 August 2006).

6 United Nations Secretary General. 2001. Support by the United Nations system of the efforts 
of Governments to promote and consolidate new or restored democracies United Nations Electoral Observer Mission for the general elections in Fiji in August 2001, General Assembly. 56th Session. Agenda item 35.

7 International Foundation for Electoral Studies.

8 International Institute for Democracy and Electoral Assistance, an inter-governmental agency based in Stockholm.

9 Semesa Karavaki, Supervisor of Elections, pers. comm. 10 March 2006.

10 The states of Africa, the Carribean, and the Pacific, in partnership with the European Union.

11 These were Sheila Roseau, executive director, Directorate of Gender Affairs, Antigua and Barbados; Keith Knight, Rajabu Kiravu; Albert Mariner; Beta Tentoa and Canon Grace Kaiso. Administrative support was provided by Christopher Child. The Commonwealth team obtained immediate and extensive media coverage and promised to report by 22 May ('We're just here to watch', Fiji Daily Post, 2 May 2006, p.2).

12 They were Mosmi Bhim, Samuala Bogitini, Jeannette Bolenga, Ian Campbell, Jon Fraenkel, Graham Hassall, Katayoun Hassall, Dolores Joseph, Mili Kaitani, Joe Ketan, Haruo Nakagawa, Rae Nicholl, Tui Rakuita, Sadhana Sen, Jagjit Singh and Etika Vulavau. Although no domestic observers were allowed, the USP team included Fiji citizens, who were granted the status of 'international observer' on the basis that the University is a regional organization. The Governance Program at USP is one of the programs run by PIAS-DG at USP.

Available at <http://www.elections.gov.f//press/20060324-2.html>.

Election Office, Guidelines for International Electoral Observers, Fiji General Elections: 6-13 May 2006.

Election Office, Guidelines for International Electoral Observers, Fiji General Elections: 6-13 May 2006.

Election Office, Article 3. Duration of International Observation. Guidelines for International Electoral Observers, Fiji General Elections: 6-13 May 2006.

18 Election Office, Article 4. Fiji Citizens. Guidelines for International Electoral Observers, Fiji General Elections: 6-13 May 2006.

19 Election Office, Article 7. Rights and Privileges of International Observers. Guidelines for International Electoral Observers, Fiji General Elections: 6-13 May 2006.

Election Office, Article 8. Obligations of International Observers Guidelines for International Electoral Observers, Fiji General Elections: 6-13 May 2006.

21 Election Office, Article 8. Obligations of International Observers. Guidelines for International Electoral Observers, Fiji General Elections: 6-13 May 2006.

Election Office, Article 9. Status of Diplomats. Guidelines for International Electoral Observers, Fiji General Elections: 6-13 May 2006. This right was not understood by some media outlets. When Ambassador Larry Dinger received headlines on 9 May for expressing concern at the number of names missing from rolls ('Poll Raises U.S. Concern', Fiji Daily Post, 9 May 2006, p.1.), his status as an 'official observer' was hotly contested in the press. Fiji Daily Post's 10 May editorial, entitled 'Larry, Curly and Moe?' asked who had invited the US ambassador to 'go around observing our national elections and commenting on them while they are in process. Who gave Larry Dinger permission to snoop around the country untrammelled and without authorization? Our elections office? The Fiji Government? Or is 
it the self-arrogating prerogative of Americans to just do what they please in other people's backyards?... There has been none of the same outspokenness from other foreign mission observers while the elections are on, but for some reason Larry has felt unencumbered by past protocols. His comments that deficiencies in the electoral process need attention and remedy are either gratuitous or designed to destabilize an already tense situation'.

'EU Official Arrives in Fiji for General Elections', Radio New Zealand International, 4 May 2006, < http://www.rnzi.com/pages/news.php?op=read\&id=23899> (accessed 26 August 2006).

24 Coutman, B. \& Chandra, J. 'Election Costs', unpublished seminar paper, University of Fiji, 2006.

Fiji Daily Post, 6 May 2006, p.3.

27 'EU Chief Observer Praises Daily Post', Fiji Daily Post, 19 May 2006, p.2.

${ }^{28}$ Fiji Daily Post, 2 May 2006, p. 1.

29 Editorial comment included 'How can the election be 'free and fair'? Isn't it already 'damaged goods'? How can Fiji have a 'free and fair' election when the commander is constantly interjecting his opinion into the democratic process - as though he were just another citizen, and without the weight of arms behind him? Are the EU and Commonwealth observers taking notes? Are they impressed with his coercive self-importance?' Fiji Daily Post, 6 May 2006, p.3.

30 Online at <http://www.europarl.europa.eu/news/expert/event_by_day_page/22-2006-150/ default_en.htm> (accessed 26 August 2006).

31 'Reasonable poll says C'wealth', Fiji Daily Post, 15 May 2006, p.3.

32 The Commonwealth's statement on counting was published in Fiji Daily Post, 20 May 2006, p. 5 under the heading 'Poll fair, now the challenges'.

33 Fiji Daily Post, 16 May 2006, p. 4.

34 Statement reproduced in Fiji Daily Post, 16 May 2006, p. 7.

35 'University of the South Pacific Observer Mission', p.7.

36 'EU Observers' verdict', Fiji Daily Post, 19 May 2006, pp.7, 9. 